\title{
Pengaruh Matematika Stokastik Pada Model Lingkungan.
}

\author{
Wahyu Fistia D \\ Jurusan Matematika FMIPA ITS
}

\begin{abstract}
Abstrak
Dua jenis yang berbeda dari model lingkungan memainkan sebuah aturan pusat di antaranya sebuah model transportasi tiga dimensi. Pada jenis model lingkungan yang berbeda didapatkan pengaruh dari matematika stokastik.

Pada penelitian ini dikembangkan model transportasi tiga dimensi dengan tujuan pendekatan numerik menggunakan persamaan diferensial stokastik. Gerakan partikel memperlihatkan arah horizontal maupun vertikal yang mengartikan konvergen lemah dan kuat.

Kata kunci : Model transportasi,persamaan differensial stokastik,konvergen.

1..Pendahuluan.

Pada tahun 1989 terjadi bencana alam yaitu kecelakaan dengan kapal pengangkut Exxon Vladez di pantai pesisir Alaska.Lebih dari 42 juta liter minyak oli mentah kebocoran diteluk Alaska.Sampai berhari-hari,kira-kira 700 kilometer dari garis pantai berminyak,akhirnya dapat ditemukan tumpahan minyak berjarak 1000 kilometer dari kecelakaan.Pengaruh oli pada tumbuhan laut dan binatang masih dirasakan sampai hari ini dengan perlahan-lahan, alam menguatkan diri dari serangan itu.

Pada penelitian ini akan dibahas tentang pengaruh yang bermacam-macam dari matematika stokastik pada jenis model lingkungan yang berbeda.Dua jenis yang berbeda dari model lingkungan mempunyai peranan penting. Pada penelitian ini model transportasi dikembangkan pada partikel dimensi tiga.
\end{abstract}

2.Persamaan Diferensial Stokastik.

Menurut Kloeden dan Platen teori persamaan diferensial stokastik dapat diperoleh dari persamaan diferensial terurut:

$$
\frac{d x}{d t}=f(t, x)
$$


sebagai sebuah bentuk degenerate dari sebuah persamaan diferensial stokastik.Dapat pula persamaan ditulis dalam bentuk simbolis sebagai:

$$
d x=f(t, x) d t
$$

Menurut Ito persamaan (2.2) penyelesaiannya adalah :

$$
\begin{gathered}
d X_{t}=\frac{1}{2} X_{t} d t+X_{t} d \beta_{t} X_{o}=1 \\
X_{o}=1
\end{gathered}
$$

Yang mempunyai penyelesaiaan eksak

$$
X_{t}=e^{\beta_{t}}
$$

Menurut Euler penyelesaian secara stokastik adalah

$$
\begin{array}{r}
Y_{n+1}=Y_{n}+\frac{1}{2} Y_{n} \Delta t+Y_{n} \Delta \beta_{n} \\
Y_{o}=1
\end{array}
$$

dimana $\Delta t$ adalah waktu diskrit untuk hitungan numerik, dan $\Delta \beta$ adalah gerakan Brownian. Secara umum penyelesaiannya adalah membagi interval $[0,1]$ dalam $10^{3}$ langkah, dan hitungan proses gerakan Brownian untuk langkah waktu (dt). Menghitung penyelesaian eksak dengan persamaan (2.4) diperoleh jika dt mendekati nol. Pada persamaan (2.5) digunakan bilangan random untuk menghitung langkah waktu $\Delta t=10^{-2}$. Sebuah penyelesaian eksak adalah pendekatan numerik seperti yang dijelaskan oleh Euler sebagai berikut

$$
\begin{gathered}
Y_{n+1}=Y_{n}+\frac{1}{2} Y_{n} \Delta t+Y_{n} \Delta \beta_{n} \\
Y_{n+1}=Y_{n}+\frac{1}{2}\left[\frac{1}{2} Y_{n}+\frac{1}{2} Y_{n+1}\right] \Delta t+\frac{1}{2}\left(Y_{n}+Y_{n+1}\right) \Delta \beta_{n} \\
Y_{o}=1
\end{gathered}
$$

Menurut teorema Taylor

$$
Y\left[\frac{1}{2}\left(t_{n}+t_{n+1}\right)\right]=\frac{1}{2} Y\left(t_{n}\right)+\frac{1}{2} Y\left(t_{n+1}\right)+O\left(\left|t_{n+1}-t_{n}\right|\right)
$$

Suku-suku order lebih tinggi tidak termasuk limit sebagai dt $\rightarrow$. 
Jika persamaan diferensial stokastik(SDE) Ito sebagai sebuah Stratanovich yang mempunyai SDE sama, tetapi dengan sebuah himpunan yang berbeda, diperoleh

$$
\begin{array}{r}
d X_{t} \operatorname{Str} \frac{1}{2} X_{t} d t+X_{t} d \beta_{t} \\
X_{o}=1
\end{array}
$$

Yang mempunyai penyelesaian eksak:

$$
X_{t}=e^{\beta_{t}+\frac{1}{2} t}
$$

Persamaan Ito yang sesuai dengan Heun yang bukan persamaan(2.3).

$$
d X_{t} \text { ItoX } X_{t} d t+X_{t} d \beta_{t}
$$

$$
X_{o}=1
$$

\section{Pandangan secara numerik}

Ada empat jenis yang berbeda yang diberikan meliputi, ekspansi Taylor stokastik,secara eksplisit, secara implisit dan ekstrapolasi.

\subsection{Ekspansi Taylor Stokastik.}

Ada beberapa cara pandangan numerik dengan order yang lebih tinggi ,yang digunakan adalah pendekatan dengan SDE(Stokastik Differensial Equation) pada ekspansi Taylor Stokastik. Sebuah persamaan differensial deterministik adalah sebuah persamaan yang mempunyai sukusuku yang lebih dari deret Taylor dengan order yang lebih tinggi secara konvergen .Perbedaan pada persamaan diferensial yang normal terletak pada deret Taylor yang stokasik, yang diferensiasinya berbeda. Anggap persamaan differensial stokastik pada suku sisa dinyatakan secara umum pada SDE satu dimensi:

$$
\begin{gathered}
d X_{t}=f\left(t, X_{t}\right) d t+g\left(t, X_{t}\right) d \beta_{t} \\
X_{t_{0}}=X_{0}
\end{gathered}
$$

\subsection{Bagan Eksplisit.}

Turunan dari koefisien diffusi harus dihitung pada setiap langkah waktu, pada penjumlahan ke koefisien waktu. Untuk mendapatkan sebuah order konvergen yang lebih tinggi seharusnya menghindari turunan. Sebuah contoh dari Heun : 


$$
\begin{gathered}
Y_{0}=1 \\
Y_{n+1}=Y_{n}+f\left(Y_{n}, t_{n}\right) \Delta t+g\left(Y_{n}, t_{n}\right) \Delta \beta_{n} \\
Y_{n+1}=Y_{n}+\frac{1}{2}\left(f\left(Y_{n}, t_{n}\right)+f\left(Y_{n+1}, t_{n+1}\right) \Delta t+\right. \\
\frac{1}{2}\left(g\left(Y_{n}, t_{n}\right)+g\left(Y_{n+1}, t_{n+1}\right)\right) \Delta \beta_{n} \ldots \ldots \ldots . . .(3.2)
\end{gathered}
$$

dimana $Y_{n+1}$ adalah prediktor Euler, dan $t_{n}=n \Delta t$.Persamaan(3.2) adalah konvergen rata-rata kuadrat pada penyelesaian Ito dari

$$
d X_{t}=\left(f\left(t, X_{t}\right)+\left.\frac{1}{2} g\left(t, X_{t}\right) \frac{\partial g}{\partial x}\right|_{\left(t, X_{t}\right)}\right) d t+g\left(t, X_{t}\right) d \beta_{t}
$$

dimana tidak sama sebagai transformasi Ito-Stratonovich dari persamaan.Menurut Rumelin, dengan mengembangkan bagan Heun dalam sebuah deret Taylor, dapat direduksi ke bentuk bagan Milstein, dan mempunyai tingkat ketelitian yang sama.Ini berarti bahwa order dengan $\gamma=1$ dan , secara logika menyelesaikan sebuah SDE Ito(Euler,Milstein), dan menyelesaikan sebuah SDE Stratonovich dengan menggunakan sebuah bagan Stratanovich ,seperti Heun atau Runge-Kutta.

Metode eksplisit dengan order lebih tinggi dapat menjadi bagan Runge-Kutta, seperti persamaan differensial berikut

$$
\begin{array}{rlrl}
K_{0} & =f\left(Y_{n}, t_{n}\right) & G_{0} & =g\left(Y_{n}, t_{n}\right) \\
Y_{n}^{(0)} & =Y_{n}+\frac{1}{2} K_{0} \Delta t+\frac{1}{2} G_{0} \Delta \beta_{i} & \\
K_{1}=f\left(Y_{n}^{(0)}, t_{n}+\frac{1}{2} \Delta t\right) & G_{1}=g\left(Y_{n}^{(0)}, t_{n}+\frac{1}{2} \Delta t\right) \\
Y_{n}^{(1)}=Y_{n}+\frac{1}{2} K_{1} \Delta t+\frac{1}{2} G_{1} \Delta \beta_{n} & \\
K_{2}=f\left(Y_{n}^{(1)}, t_{n}+\frac{1}{2} \Delta t\right) & G_{2}=g\left(Y_{n}^{(2)}, t_{n}+\frac{1}{2} \Delta t\right) \\
Y_{n}^{(2)}=Y_{n}+K_{2} \Delta t+G_{2} \Delta \beta_{n} & \\
K_{3}=f\left(Y_{n}^{(2)}, t_{n}+\Delta t\right) & G_{3}=g\left(Y_{n}^{(2)}, t_{n}+\Delta t\right) \\
Y_{n+1}=Y_{n}+\frac{1}{6}\left(K_{0}+2 K_{1}+2 K_{2}+K_{3}\right) \Delta t+\frac{1}{6}\left(G_{0}+2 G_{1}+2 G_{2}+G_{3}\right) \Delta \beta_{n}
\end{array}
$$

3.3 Bagan Implisit. 
Sebuah bagan implisit adalah bagian implisit Euler dimana errornya diakumulasi :

$$
\begin{aligned}
Y_{0} & =1 \\
Y_{n+1} & =Y_{n}+f\left(Y_{n+1}, t_{n+1}\right) \Delta t+g\left(Y_{n}, t_{n}\right) \Delta \beta_{n}
\end{aligned}
$$

Sebuah interpolasi linier dibentuk diantara jenis eksplisit dan implisit dari bagian yang sama dengan memilih sebuah parameter tertentu $0 \leq \alpha \leq 1$ :

$$
\begin{gathered}
Y_{0}=1 \\
Y_{n+1}=Y_{n}+\left[\alpha f\left(Y_{n+1}, t_{n+1}\right)+(1-\alpha) f\left(Y_{n}, t_{n}\right)\right] \Delta t+g\left(Y_{n}, t_{n}\right) \Delta \beta_{n} \ldots
\end{gathered}
$$

dimana $\alpha=0$ memerikan bagan eksplisit Euler, $\alpha=0.5$ memberikan hasil bagan trapezoidal, dan dengan $\alpha=1$ memberikan bagan implisit Euler. Pada kejadian sebuah SDE linier :

$$
d X_{t}=\left(a_{1}(t) X_{t}+b_{t}(t)\right) d t+\left(a_{2}(t) X_{t}+b_{2}(t)\right) d \beta_{t} \ldots .
$$

Adalah sebuah rumus eksplisit yang diperoleh melalui manipulasi aljabar. Pada kejadian lain,sebuah persamaan aljabar harus diselesaikan pada setiap langkah,untuk sebuah metode numerik seperti Newton-Raphson. Konvergen dari metode implisit (bagan trapezoidal dan bagan implisit Euler) adalah sama sebagai bagan Eksplisit Euler : $\gamma=\frac{1}{2}$ dan $=1$ (Kloden) yang juga konvergen ke penyelesaian sebagai bagan Eksplisit Euler.

Kejadian yang sama juga dikerjakan oleh bagan Euler yang mungkin untuk bagan Milstein. Bagian penting dari bagan implicit Milstein()mempunyai versi Ito :

$$
Y_{0}=1
$$

$Y_{n+1}=Y_{n}+f\left(Y_{n+1}, t_{n+1}\right) \Delta t+g\left(Y_{n}, t_{n}\right) \Delta \beta_{n}+\frac{1}{2} g\left(Y_{n}, t_{n}\right)\left\{\left(\Delta \beta_{n}\right)^{2}-\Delta t\right\} \ldots .(3.6)$

Pada kejadian ini,konvergen diperoleh untuk bagan eksplisit Milstein.

\subsection{Bagan Ekstrapolasi}

Sebuah pilihan dan mungkin cara yang lebih mudah untuk mendapatkan konvergen yang lebih cepat dengan menggunakan metoda ekstrapolasi.Metoda ini menggunakan bagan dengan order yang lebih rendah untuk mendapatkan sebuah metoda dengan order yang lebih tinggi.

Pada kejadian deterministik oleh Kloeden untuk sebuah konsep umum.Misalkan menggunakan bagan Euler terhadap interval waktu $0 \leq t \leq T$ dengan $\mathrm{N}$ langkah sama ke $\Delta t=T /{ }_{N}$. Misal $x(T)$ adalah sebuah nilai yang benar pada waktu $T$ dan $y_{n}(T)$ sesuai ke pendekatan numerik dari bagan Euler.Untuk error truncation keseluruhan dapat ditulis

$$
y_{n}(\Delta t)-x(T)=e(T) \Delta t+O\left(\Delta t^{2}\right)
$$


Jika digunakan dua kali sebagai beberapa langkah, error berubah ke

$$
y_{2 N}\left(\frac{1}{2} \Delta t\right)-x(T)=\frac{1}{2} e(T) \Delta t+O\left(\Delta t^{2}\right)
$$

Selanjutnya, $e(T)$ dapat dieliminasi , dan hasilnya

$$
x(T)=2 y_{2 n}\left(\frac{1}{2} \Delta t\right)-y_{N}(\Delta t)+O\left(\Delta t^{2}\right)
$$

Sebuah pendekatan order kedua dapat dirumuskan dari bagan Eueler, yang disebut ekstrapolasi Richardson atau Romberg:

$$
R_{N}(\Delta t)=2 y_{2 N}\left(\frac{1}{2} \Delta t\right)-y_{N}(\Delta t)
$$

Sebuah perbaikan untuk teknik bagan Euler harus dievaluasi dua kali: satu kali dengan langkah waktu $\Delta t$, dan satu kali dengan langkah waktu $\frac{1}{2} \Delta t$.Pada kejadian persamaan differensial lengkap, mungkin lebih murah daripada menggunakan bagan order dua.Metoda ini diterapkan ke sebuah jenis yang lebar dari bagan lain untuk mendapatkan sebuah konvergen yang lebih tinggi.

4.Kesimpulan.

Dari pembahasan sebelumnya diperoleh kesimpulan bahwa didapatkan tingkatan konvergen dengan hasil akurat dari pendekatan numerik pada arahvertikal dan horizontal.

Untuk penelitian selanjutnya dapat diterapkan pada model stokastik yang berkualitas pada sungai dengan metode numerik order lebih tinggi.

\section{DAFTAR PUSTAKA}

1. Arnold, L “Stochastic Differential Equations”,Willey, New York, 1974.

2. Einstein, A, "Investigation on Theory of the Brownian Movement", Dover Publications, 180 Varick Street, New York,N.Y.10014, 1926.

3. Fischer,H.B, List, E.J, Koh,R,C, Y, Imberger,J and Brooks , N. H, “ Mixing in Inland and Coastal Waters, “Academic Press, San Diego, 1979.

4. Gardiner, C.W, "Handbook of Stochastic Methods for physics ,Chemistry and Natural Sciences, “, Springer-Verlag, Berlin, 1983.

5. Ito,K, “On Stochastic Differential Equations, “ „Memoirs Amer. Math.Soc.4, 1951. 
6. Ito,K, "Lectures on Stochastic Processes", memographed notes, Tata Institute of Fundamental Research, Bombay,India, 1961.

7. Jazwinsky, AH, "Stochastic Processes and Filtering Theory, " Academic Press, New York, 1970.

8. Kloeden, P.E and Platen, E, "Numerical Solution of Stochastic Differential Equations, “ Springer-Verlag,New York, 1995.

9. Pristley, M.B, “ Spectral Analysis and Time Series“, Academic Press Limited, 24-28 Oval Road, London NW1 7DX, 1996.

10. Rumelin,W, "Numerical Treatment of Stochastic Differential Equations, "SiamJ. Numer Anmal, 19. 3 (June 1982), pp604-613.

11. Stratonovich, R,L , "Topics in the Teory of Random Noise", vol 2,translated from Russian by R.A Solverman, “ Gordon Breach, New York, 1967.

12. Taylor, G.I, "Diffusion by Continous Movements", Proc.London. Math. Soc. Ser. A20 .1921, 196-211.

13. Van Kampen, N.G,'Stochastic Processes in Physics and Chemistry",Noth-Holland Publishing Company,1981. 
